\title{
Analisis Tingkat Kepuasan Pasien Swamedikasi Terhadap Mutu Pelayanan Kefarmasian di Apotek (Kelurahan Mojolangu Kecamatan Lowokwaru Kota Malang)
}

\section{Liza Pristianty $^{1 *}$, Hefti Ari Fransiska ${ }^{2}$, Mutiara Titani ${ }^{3}$}

1Departemen Farmasi Praktis, Fakultas Farmasi, Universitas Airlangga, Surabaya, Jawa Timur, Indonesia

²Program Studi Farmasi, Fakultas Ilmu Kesehatan, Universitas Muhammadiyah Malang, Malang, Jawa Timur, Indonesia

${ }^{3}$ Program Studi Farmasi, Fakultas Ilmu Kesehatan, Universitas Muhammadiyah Malang, Malang, Jawa Timur, Indonesia

*email: liza-p@ff.unair.ac.id

(Submit 19/12/2021, Revisi 20/12/2021, Diterima 30/12/2021, Terbit 31/12/2021)

\begin{abstract}
Abstrak
Swamedikasi merupakan upaya penanganan penyakit ringan yang sering terjadi di masyarakat dan menjadi solusi untuk meningkatkan keterjangkauan pengobatan. Hal ini harus dilakukan dengan hati-hati agar tidak terjadi kesalahan pengobatan. Apoteker di apotek diharapkan dapat membantu masyarakat melakukan swamedikasi untuk meningkatkan kualitas pelayanan di apotek dan mendukung kepuasan pasien. Penelitian ini bertujuan untuk menganalisis tingkat kepuasan pasien swamedikasi terhadap mutu pelayanan kefarmasian di apotek wilayah Mojolangu, Malang.Penelitian ini merupakan penelitian deskriptif dengan jumlah sampel 100 responden. Teknik pengambilan sampel secara purposive sampling dan instrumen yang digunakan kuesioner dengan skala likert. Terhadap kuesioner terlebih dahulu dilakukan uji validitas dan reliabilitas. Dan data yang diperoleh dianalisis menggunakan metode Servqual and Importance Performance Analysis (IPA). Hasil analisis metode servqual diperoleh skor negatif (-) pada semua indikator pertanyaan, berarti responden tidak puas dengan pelayanan apotek di Mojolangu, Malang. Sedangkan pada analisis dengan Importance Performance Analysis (IPA) diperoleh rata-rata total ( $X$ ) pada variabel realita adalah 4,10 dan pada variabel ekspektasi 4,55. Dari hasil tersebut dapat disimpulkan bahwa responden tidak puas dengan pelayanan yang diberikan oleh apotek di Mojolangu, Malang. Pelayanan yang perlu diprioritaskan untuk ditingkatkan adalah kemampuan apoteker memberikan informasi tentang obat.
\end{abstract}

Kata kunci: apotek, kualitas pelayanan, swamedikasi, tingkat kepuasan pasien 


\section{Pendahuluan}

Kesehatan menurut Undang-Undang Nomor 36 Tahun 2009 adalah kondisi badan, jiwa, dan sosial seseorang yang sejahtera hingga membuat setiap orang hidup produktif baik secara sosial dan ekonomi. ${ }^{1}$ Pelayanan kesehatan merupakan suatu usaha yang menjadikan individu untuk mengembangkan kesehatan, serta mengobati penyakit yang diderita. $^{2}$ Salah satu pemberi pelayanan kesehatan kepada masyarakat yang mempunyai peranan penting adalah pelayanan kefarmasian. Pelayanan kefarmasian adalah suatu pelayanan berkaitan dengan obat dan penggunaannya yang benar agar tercapai kualitas hidup masyarakat yang baik. ${ }^{3}$ Pelayanan kefarmasian dilakukan oleh apoteker baik dalam bentuk pelayanan obat resep maupun pelayanan swamedikasi. ${ }^{4}$

Swamedikasi adalah usaha mengobati keluhan-keluhan dan penyakit ringan yang banyak dialami diri-sendiri yang menjadi alternatif yang diambil masyarakat untuk meningkatkan keterjangkauan pengobatan. ${ }^{5}$ Swamedikasi saat ini semakin banyak dilakukan di masyarakat, menjadi alternatif yang banyak dipilih untuk meredakan keluhan kesehatan. Swamedikasi yang bertanggung jawab adalah penggunaan obat secara tepat berdasarkan inisiatif sendiri, keputusan memilih dan menggunakan obat. Swamedikasi yang tidak dilakukan dengan benar akan menimbulkan resiko yaitu kesalahan mendiagnosis diri, kesalahan menentukan dosis, timbul interaksi berbahaya. ${ }^{6}$ Menurut data Badan Pusat Statistik (BPS) terjadi peningkatan persentase masyarakat yang melakukan swamedikasi pada tahun $201663,77 \%$, pada tahun $201769,43 \%$ dan pada tahun 2018 70.74\%. ${ }^{7}$ Apotik merupakan sarana kefarmasian utama oleh apoteker dalam pelayanan swamedikasi kepada masyarakat, dengan demikian mutu pelayanan swamedikasi di apotek akan mempengaruhi kepuasan pasien. ${ }^{8}$

Mutu pelayanan kefarmasian yang diberikan apoteker di apotek akan berpengaruh terhadap kepuasan pasien. ${ }^{9}$ Kepuasan mencerminkan penilaian seseorang tentang kinerja produk anggapannya (hasil) dalam kaitannya dengan ekspektasi. ${ }^{10}$ Mutu pelayanan di apotek, tidak hanya dari harga obat tetapi juga pelayanan kefarmasian, yang dilakukan oleh apotek tersebut. ${ }^{11}$ Pelayanan yang baik otomatis akan membuat konsumen menjadi puas dan akan mempunyai tingkat loyalitas yang tinggi. ${ }^{12}$ Konsep kualitas layanan yang berkaitan dengan kepuasan ditentukan oleh lima unsur, yaitu responsibility, assurance, tangible, emphaty, dan reliability, yang dikenal dengan istilah 'RATER'. ${ }^{13}$ Kualitas layanan RATER digunakan sebagai acuan dalam mewujudkan layanan di bidang usaha untuk memecahkan berbagai kesenjangan yang terjadi dalam memenuhi tuntutan masyarakat Inti dari konsep kualitas layanan adalah menunjukkan bentuk aktualisasi kegiatan pelayanan yang memuaskan orang yang menerima pelayanan sesuai dengan ketanggapan (responsiveness), jaminan kepastian (assurance), bukti fisik (tangible) yang dapat dilihatnya, empati (empathy) dari orangorang yang memberikan pelayanan sesuai dengan kehandalannya menjalankan tugas pelayanan (reliability). ${ }^{14}$

Berdasarkan uraian tersebut, pada penelitian ini ingin diketahui tingkat kepuasan pasien swamedikasi terhadap mutu pelayanan kefarmasian pada beberapa Apotek di kelurahan Mojolangu kecamatan Lowokwaru kota Malang, alasan dipilih wilayah 
tersebut karena menurut Badan Pusat Statistik kelurahan Mojolangu memiliki jumlah penduduk terbesar di kecamatan Lowokwaru. Lowokwaru juga merupakan kecamatan dengan kepadatan penduduk terbesar di kota Malang.

\section{Metode}

Penelitian ini merupakan jenis penelitian deskriptif yang dilakukan secara crossesctional. ${ }^{15}$ Populasi dalam penelitian ini adalah seluruh pasien yang datang membeli obat tanpa resep dokter di apotek kelurahan Mojolangu. Sedangkan sampel yang digunakan adalah yang memenuhi kriteria inklusi yaitu berusia diatas 18 tahun, dapat membaca, menulis dan bersedia mengisi kuisioner. Metode sampling yang digunakan adalah Non Probability sampling yaitu Purposive sampling. ${ }^{16}$ Besar sampel penelitian 100 responden. Penelitian dilakukan pada bulan Januari - Februari 2020, lokasi penelitian dilakukan di Apotek kelurahan Mojolangu kecamatan Lowokwaru kota Malang. instrumen penelitian menggunakan kuisioner yang mengandung butir pertanyan dengan variable responsiveness, assurance, tangible, empathy dan reliability. Data dianalisis menggunakan servqual dan IPA (Importance Performance Analysis).

\section{Hasil}

Karakteristik demografi pasien swamedikasi pada penelitian ini meliputi umur, jenis kelamin, pendidikan dan pekerjaan. Diketahui pasien yang paling banyak melakukan swamedikasi pada usia $18-25$ (32\%), jenis kelamin perempuan (55\%), pendidikan terakhir SMA (48\%) dengan pekerjaan sebagai wirausaha (36\%). Gambaran demografi pasien swamedikasi dapat dilihat pada Tabel 1.

Tabel 1 Data demografi pasien swamedikasi

\begin{tabular}{lcc}
\hline Karakteristik Demografi & Katagori & Frekwensi/Persentase \\
\hline Usia & $19-25$ & $32(32 \%)$ \\
& $26-35$ & $18(18 \%)$ \\
& $36-45$ & $24(24 \%)$ \\
& $46-55$ & $13(13 \%)$ \\
& $56-65$ & $7(7 \%)$ \\
& $>65$ & $6(6 \%)$ \\
\hline Jenis kelamin & Laki-laki & $55(55 \%)$ \\
& Perempuan & $45(45 \%)$ \\
\hline Pendidikan & SD & $3(3 \%)$ \\
& SMP & $16(16 \%)$ \\
& SMA & $48(48 \%)$ \\
\hline Pekerjaan & Perguruan Tinggi & $33(33 \%)$ \\
& PNS & $3(3 \%)$ \\
& Wirausaha & $36(36 \%)$ \\
& Karyawan & $30(30 \%)$ \\
& Mahasiswa & $21(21 \%)$ \\
IRT & $10(10 \%)$ \\
\hline
\end{tabular}


Gambaran hasil tersebut sesuai dengan penelitian Harahap (2017) bahwa swamedikasi banyak dilakukan oleh golongan usia muda dibawah 30 tahun. ${ }^{17}$ Berdasarkan jenis kelamin perempuan lebih banyak dari pada laki-laki karena umumnya perempuan lebih cepat merespon kebutuhan pengobatan baik untuk diri sendiri maupun untuk keluarganya. Sedangan Pendidikan terkahir adalah SMA, hal ini sesuai pernyataan yang dikeluarkan oleh PAHO (Pan American Health Organization) bahwa swamedikasi meningkat pada populasi penduduk dengan tingkat pendidikan yang lebih tinggi ${ }^{18}$, tingkat pendidikan turut mempengaruhi penilaian pasien terhadap informasi yang diberikan pada pelayanan swamedikasi. Swamedikasi banyak dilakukan oleh pasien yang memiliki pekerjaan sebagai wirausaha (36\%), dengan kesibukan yang tinggi, mereka menjadi lebih mudah, praktis dan tidak mengganggu aktivitasnya (Husnawati et al,. 2015).

Hasil analisis metode Servqual untuk mengetahui penilaian pasien swamedikasi terhadap kinerja pelayanan kefarmasian di apotek dan harapannya. Skor yang dihasilkan merupakan selisih antara kinerja dan harapan. Dari Tabel 2 diketahui skor nilai yang diperoleh negatif yang artinya rata-rata hasil penilaian pasien swamedikasi terhadap pelayanan dirasakan lebih kecil dibanding yang diharapkan dari dimensi responsiveness, reliability, emphaty, assurance dan tangible. Hal ini berarti pasien swamedikasi tidak puas dengan kinerja pelayanan swamedikasi di apotek di Mojolangu, Malang. Hasil selengkapnya dapat dilihat pada Tabel 2.

Dari Tabel 2 diketahui tingkat kesesuaian berdasarkan metode Importance Performance Anaysis (IPA) ${ }^{14}$ bahwa tingkat kesesuaian pada dimensi responsiveness $92,2 \%$, reliability $84,7 \%$, assurance $90,7 \%$, Tangible $87,5 \%$ dan empathy $94,9 \%$. Dari gambaran tersebut dapat dinyatakan meskipun pasien swamedikasi tidak puas dengan pelayanan yang diberikan oleh apotek di Mojolangu Kota Malang tetapi selisih antara harapan dan kinerja tidak terlalu berbeda jauh. Ketanggapan kesopanan dan keramahan petugas apotek dan jaminan pelayanan obat oleh apoteker di apotek menunjukkan nilai Tingkat kesesuaian ditas 90\%. Tingkat kesesuaian antara kinerja dan harapan pada dimensi tangible $87,5 \%$ hal ini menunjukkan bahwa fasilitas yang disediakan oleh apotek kurang memadai menurut pasien, sedangkan untuk dimensi reliability nilai tingkat kesesuaian yang terendah yaitu $84,7 \%$ hal ini menunjukkan bahwa di apotek Mojolangu Kota Malang masih banyak yang tidak memberikan layanan konsultasi saat pasien swamedikasi di apotek. Berdasarkan tingkat kesesuaian dari masing-masing dimensi, selanjutnya dilakukan pemetaan diagram kartesius dalam bentuk 4 kuadran untuk menetapkan prioritas pelayanan ${ }^{19}$ seperti pada Gambar 1.

\section{Pembahasan}

Kuadran A merupakan Prioritas Utama (Concentrate Here), adalah wilayah yang memuat faktor yang dianggap penting oleh pasien, tetapi pada kinerja belum sesuai dengan harapan (tingkat kepuasan yang diperoleh masih rendah). Dengan demikian indicator pada dimensi tersebut harus ditingkatkan. Pada peneitian ini yang termasuk dalam Kuadran $A$ adalah pernyataan 4 yaitu petugas apotek memberikan informasi obat yang di beli c(Khasiat, aturan pakai, dosis, interaksi, efek samping, kontraindikasi, cara penyimpanan, lama penggunaan obat). Hal ini menunjukkan bahwa apotek di Mojolangu Kota Malang tidak memberikan informasi tentang obat kepada pasien swamedikasi. ${ }^{20}$ 
Tabel 2 Hasil analisis metode servqual dan metode importance performance analysis (IPA)

\begin{tabular}{|c|c|c|c|c|c|c|c|}
\hline Dimensi & No & Item Pertanyaan & $\begin{array}{c}\text { Rata-rata } \\
\text { skor } \\
\text { Kinerja } \\
\bar{X}\end{array}$ & $\begin{array}{c}\text { Rata-rata } \\
\text { skor } \\
\text { Harapan } \\
\bar{Y}\end{array}$ & $\begin{array}{c}\text { Score } \\
\text { servqua } \\
\quad \begin{array}{l}\mathrm{I} \\
\bar{X}-\bar{Y}\end{array}\end{array}$ & $\begin{array}{c}\text { Tingkat } \\
\text { Kepuasa } \\
\mathbf{n}\end{array}$ & $\begin{array}{l}\text { Tingkat } \\
\text { Kesesuai } \\
\text { an } \\
\text { (IPA) }\end{array}$ \\
\hline \multirow[t]{4}{*}{$\begin{array}{l}\text { Respons } \\
\text { iveness }\end{array}$} & 1 & $\begin{array}{l}\text { Petugas Apotek cepat } \\
\text { dan tanggap dalam } \\
\text { melayani pasien }\end{array}$ & 4.53 & 4.76 & -0.23 & $\begin{array}{l}\text { Tidak } \\
\text { Puas }\end{array}$ & $95.1 \%$ \\
\hline & 2 & $\begin{array}{l}\text { Petugas Apotek } \\
\text { menanyakan obat } \\
\text { yang sedang di } \\
\text { konsumsi saat ini }\end{array}$ & 3.84 & 4.46 & -0.62 & $\begin{array}{l}\text { Tidak } \\
\text { Puas }\end{array}$ & $86.1 \%$ \\
\hline & 3 & $\begin{array}{l}\text { Petugas Apotek } \\
\text { menanggapi/ } \\
\text { menjawab } \\
\text { pertanyaan saya } \\
\text { dengan baik }\end{array}$ & 4.41 & 4.62 & -0.21 & $\begin{array}{l}\text { Tidak } \\
\text { Puas }\end{array}$ & $95.4 \%$ \\
\hline & & & & & & & $92,2 \%$ \\
\hline \multirow[t]{10}{*}{$\begin{array}{l}\text { Reliabilit } \\
y\end{array}$} & 4 & $\begin{array}{l}\text { Petugas Apotek } \\
\text { memberikan }\end{array}$ & 3.88 & 4.78 & -0.90 & $\begin{array}{l}\text { Tidak } \\
\text { Puas }\end{array}$ & $81.1 \%$ \\
\hline & & $\begin{array}{l}\text { informasi obat yang } \\
\text { saya beli }\end{array}$ & & & & & \\
\hline & & $\begin{array}{l}\text { (Khasiat, aturan pakai, } \\
\text { dosis, interaksi, efek } \\
\text { samping, }\end{array}$ & & & & & \\
\hline & & $\begin{array}{l}\text { kontraindikasi, cara } \\
\text { penyimpanan, lama } \\
\text { penggunaan obat) }\end{array}$ & & & & & \\
\hline & 5 & $\begin{array}{l}\text { Petugas Apotek } \\
\text { memberi saran }\end{array}$ & 3.57 & 4.42 & -0.85 & $\begin{array}{l}\text { Tidak } \\
\text { Puas }\end{array}$ & $80.7 \%$ \\
\hline & & $\begin{array}{l}\text { konsultasi ke dokter } \\
\text { apabila obat yang } \\
\text { saya beli tidak dapat }\end{array}$ & & & & & \\
\hline & & $\begin{array}{l}\text { menyembuhkan gejala } \\
\text { yang saya alami }\end{array}$ & & & & & \\
\hline & & $\begin{array}{l}\text { Petugas Apotek } \\
\text { memberikan }\end{array}$ & 4.35 & 4.70 & -0.35 & $\begin{array}{l}\text { Tidak } \\
\text { Puas }\end{array}$ & $92.5 \%$ \\
\hline & & $\begin{array}{l}\text { informasi dengan jelas } \\
\text { dan bahasa yang } \\
\text { mudah dimengerti }\end{array}$ & & & & & \\
\hline & & & & & & & $84,7 \%$ \\
\hline \multirow[t]{3}{*}{$\begin{array}{l}\text { Assuran } \\
\text { ce }\end{array}$} & 6 & $\begin{array}{l}\text { Obat yang saya cari di } \\
\text { apotek ini selalu ada }\end{array}$ & 4.01 & 4.51 & $\begin{array}{l}-0.50 \\
\end{array}$ & $\begin{array}{l}\text { Tidak } \\
\text { Puas }\end{array}$ & $88.9 \%$ \\
\hline & 7 & $\begin{array}{l}\text { Obat yang dijual di } \\
\text { apotek ini harganya } \\
\text { terjangkau }\end{array}$ & 4.23 & 4.51 & $\begin{array}{l}-0.28 \\
\end{array}$ & $\begin{array}{l}\text { Tidak } \\
\text { Puas }\end{array}$ & $93.8 \%$ \\
\hline & 8 & $\begin{array}{l}\text { Pelayanan obat } \\
\text { maupun konsultasi } \\
\text { dilakukan oleh } \\
\text { apoteker }\end{array}$ & 4 & 4.48 & -0.48 & $\begin{array}{l}\text { Tidak } \\
\text { Puas }\end{array}$ & $89.3 \%$ \\
\hline
\end{tabular}




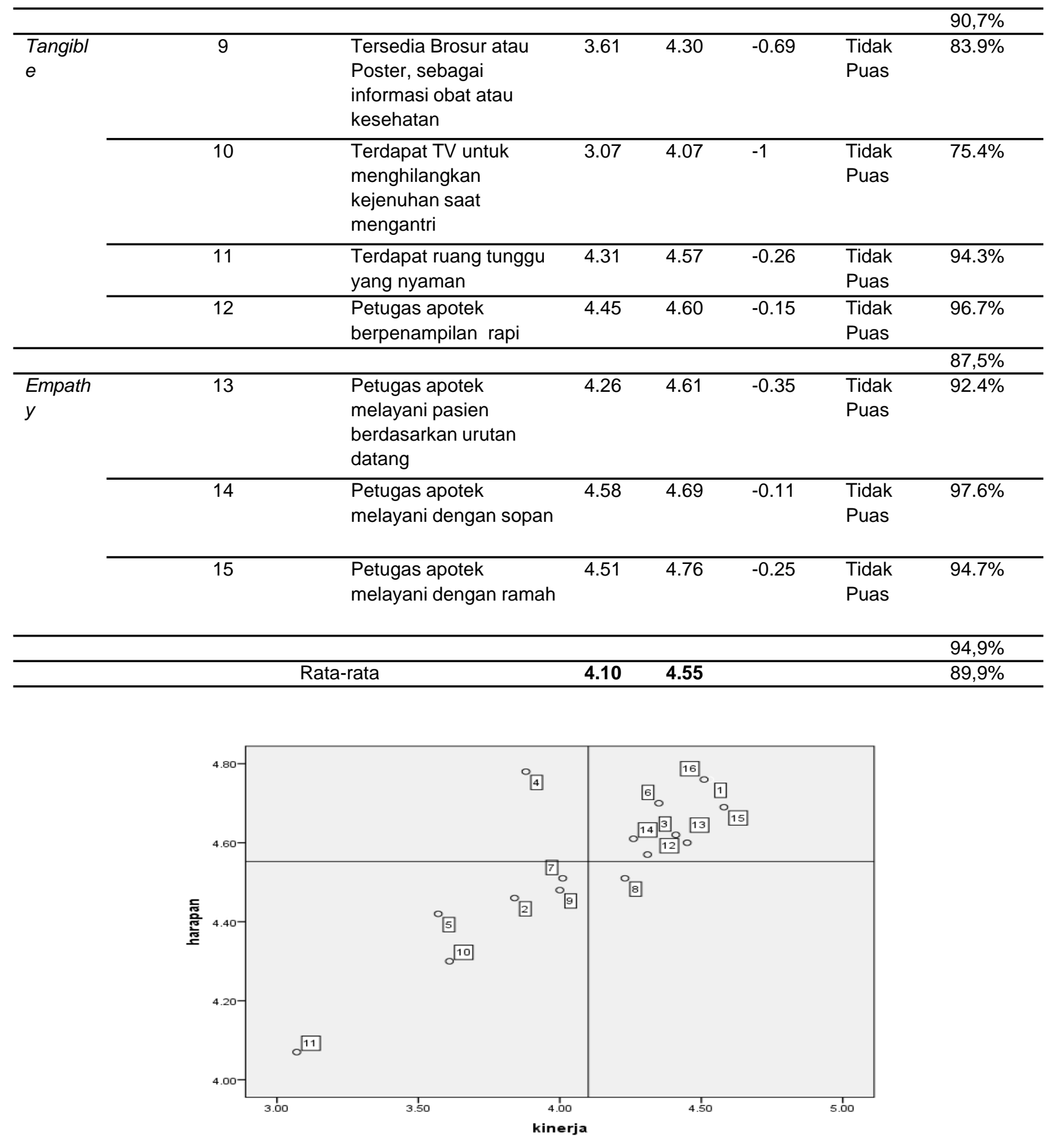

Gambar 1 Hasil pemetaan diagram kartesius

Kuadran B Prestasi dipertahaankan (Keep Up The Good Work) adalah wilayah yang memuat faktor yang dianggap penting oleh pasien dan faktor tersebut dianggap pelanggan sudah sesuai dengan yang dirasakannya sehingga tingkat kepuasannya relatif lebih tinggi. Indikator dalam kuadran ini tetap dipertahankan karena menjadikan produk atau jasa unggul di mata pelanggan. ${ }^{21}$ Dalam penelitian ini yang masuk dalam Kuadran B adalah pernyataan nomor 1;3;6;12;13;14; 15;16. 
Kuadran C Prioritas Rendah (Low Priority) adalah wilayah yang memuat faktor yang dianggap kurang penting dan pada kenyataannya kinerjanya tidak istimewa. Peningkatan indicator yang termasuk dalam kuadran ini dapat dipertimbangkan kembali karena pengaruh yang dirasakan oleh pelanggan kecil. 22 Dalam penelitian ini yang masuk dalam Kuadran $C$ adalah pernyataan nomor 2;5;7;9;6; 10;11.

Kuadran D Berlebihan (Possibly Overkill) adalah kuadran yang mendapat pelayanan yang berlebihan dan kurang dianggap penting oleh pelanggan. Indikator dalam kuadran ini dapat diturunkan pelayanannnya untuk menghemat biaya. ${ }^{23}$ Dalam penelitian ini yang masuk dalam Kuadran D adalah pernyataan nomor 8.

\section{Kesimpulan}

1. Dari analisis metode servqual, pasien swamedikasi di apotek Mojolangu Kota Malang tidak puas dengan mutu pelayanan yang diberikan oleh apotek dari dimensi responsiveness, reliability, assurance, tangible dan emphathy karena skor harapan lebih tinggi dari kinerja

2. Dari analisis IPA, tingkat kesesuaian kinerja mendekati harapan. Tingkat kesesuaian tertinggi pada emphathy $94,7 \%$ dan terendah reliability $84,7 \%$

3. Indikator yang perlu ditingkatkan kinerjanya adalah memberikan informasi obat kepada pasien swamedikasi di apotek Mojolangu Kota Malang.

\section{Daftar Pustaka}

1. Undang-Undang Republik Indonesia Nomor 36 Tahun 2009 Tentang Kesehatan.

2. Depkes RI. Profil Kesehatan Indonesia. Jakarta: DepKes RI; 2009a.

3. Depkes RI. Standar pelayanan kefarmasian di apotek. In Peraturan Menteri Kesehatan Republik Indonesia (Issue 35, pp. 1-33). Jakarta: DepKes RI; 2014

4. Depkes RI. Pekerjaan Kefarmasian: Peraturan Menteri RI, 51, 1-12. Jakarta: DepKes Rl; 2009b.

5. Ruiz M. Risks of self-medication practices. Current Drug Safety. 2010;5(4):1-22.

6. Alghanim SA, Self-medication practice among patients in a public health care system. Eastern Mediterranean Health Journal La Revue de Santé de la Méditerranée orientale (EMHJ). 2011;17(5):409-416.

7. Biro Pusat Statistik. 2019. Nomor Katalog: 1101001, Nomor Publikasi: 03220.1911, ISSN/ISBN: 0126-2912

8. Depkes RI. Standar Pelayanan Kefarmasian di Apotek. In Peraturan Menteri Kesehatan Republik Indonesia (Issue 35, pp. 1-33). Jakarta: DepKes RI; 2014.

9. Ihsan S, Rezkya P, Akib NI. kefarmasian oleh apoteker pengelola apotek di apotek-apotek kota Kendari. Medula. 2014;2(1):119-125. 
10. Kotler, Philip, Keller KL. Manajemen pemasaran (Edisi ke-13). Jakarta: Erlangga; 2009

11. Kartajaya H. Hermawan Kartajaya on marketing Mix. Bandung: Mizan; 2006.

12. Putri DR. Pengaruh kualitas pelayanan kefarmasian terhadap kepuasan, kepercayaan, \& loyalitas konsumen apotek. Indonesian Journal for Health Sciences. 2017;1(1):23-29.

13. Parasuraman A, Berry LL, Zeithaml VA. SERVQUAL: A multiple-item scale for measuring consumer perceptions of service quality. Journal of Retailing. 1988;64(1):12-40.

14. Supranto J. Pengukuran tingkat kepuasan pelanggan untuk menaikkan pangsa pasar, cetakan keempat, Jakarta: Penerbit PT Rineka Cipta; 2011.

15. Kuntoro $\mathrm{H}$. Metode sampling dan penentuan besar sampel. Surabaya: Pustaka Melati; 2008.

16. Notoatmodjo S. Metodologi penelitian kesehatan, PR. Jakarta: PT. Rineka Cipta; 2010

17. Harahap NA, Khairunnisa K, Tanuwijaya J. Tingkat pengetahuan pasien dan rasionalitas swamedikasi di tiga apotek kota Panyabungan. Jurnal Sains Farmasi \& Klinis. 2017;3(2):186.

18. PAHO. Drug classification: prescription and OTC drugs. Washington, D.C.: PAHO; 2004.

19. Nugraha $R$, Ambar $H$, Adianto $H$. Usulan peningkatan kualitas pelayanan jasa pada bengkel " $X$ " berdasarkan hasil matrix importance-performance analysis (studi kasus di bengkel AHASS PD. Sumber Motor Karawang). Jurnal Online Institut Teknologi Nasional. 2014;1(3):221-231.

20. Putri DR. Pengaruh kualitas pelayanan kefarmasian terhadap kepuasan, kepercayaan, \& loyalitas konsumen apotek. Indonesian Journal for Health Sciences. 2017;1(1):23-29.

21. Nugraha $R$, Ambar $H$, Adianto $H$. Usulan peningkatan kualitas pelayanan jasa pada bengkel " $X$ " berdasarkan hasil matrix importance-performance analysis (studi kasus di bengkel AHASS PD. Sumber Motor Karawang). Jurnal Online Institut Teknologi Nasional. 2014;1(3):221-231.

22. Hakim MAL, Putro BL, Wahyudin A. Sisten Pengukur Kualitas Layanan Pendidikan Menggunakan Educational Quality. Jurnal Pendidikan Teknologi Informasi dan Komunikasi. 2014;7(9):1689-1699.

23. Dewi SK, Putri ARC, Winarko BAD. Peningkatan Kualitas Jasa Fasilitas Kesehatan dengan Integrasi Metode IPA dan KANO. Jurnal Sistem Dan Manajemen Industri. 2018;2(2);67-76. 